\title{
Pengaruh Konflik Peran, Stres Kerja, dan Pemahaman Good Governance Terhadap Kinerja Auditor
}

\author{
Virginia Xena Francisca Talise ${ }^{1}$ \\ Fakultas Ekonomi dan Bisnis Universitas Udayana, Indonesia. \\ Email: virginiatalise@gmail.com
}

\begin{abstract}
ABSTRAK
Agar auditor memiliki kinerja yang baik, suatu perusahaan atau Kantor Akuntan Publik perlu memperhatikan faktor-faktor yang mempengaruhi kinerja auditornya. Tujuan penelitian ini adalah untuk menguji dan memberi bukti empiris pada pengaruh konflik peran, stres kerja dan pemahaman good governance terhadap kinerja auditor. Penelitian ini dilakukan di Kantor Akuntan Publik yang terdaftar dalam Direktori yang diterbitkan oleh Institute Akuntan Publik Indonesia tahun 2018 yang berjumlah 8 kantor dengan sampel 60 orang auditor. Berdasarkan hasil analisis ditemukan bahwa Konflik peran secara parsial berpengaruh negatif dan signifikan terhadap kinerja auditor. Stres kerja secara parsial tidak berpengaruh terhadap kinerja auditor. Pemahaman good governance secara parsial berpengaruh positif dan signifikan terhadap kinerja auditor.
\end{abstract}

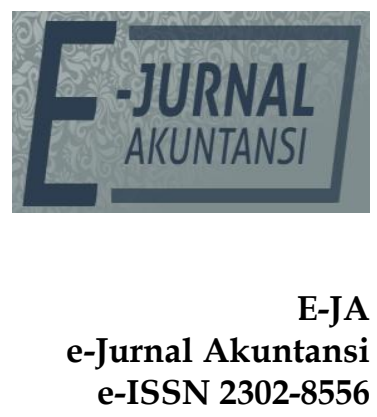

Kata Kunci : Konflik Peran; Stres Kerja; Pemahaamn Good Governance; Kinerja.

Vol.298 No. 1

Denpasar, Oktober

2019

\section{Effects of Role Conflict, Job Stress, and Understanding of Good Governance on Auditor Performance}

\section{ABSTRACT}

In order for auditors to have good performance, a company or Public Accountant Office needs to pay attention to the factors that influence the performance of its auditors. The purpose of this study is to examine and provide empirical evidence on the influence of role conflict, work stress and understanding good governance on auditor performance. This research was conducted at the Public Accounting Firm registered in the Directory published by the Indonesian Institute of Certified Public Accountants in 2018, which amounted to 8 offices with a sample of 60 auditors. Based on the results of the analysis it was found that role conflict partially had a negative and significant effect on auditor performance. Job stress partially does not affect auditor performance. Understanding of good governance partially has a positive and significant effect on auditor performance.

Keywords: $\quad$ Role Conflict; Work Stress; Understanding Of Good Governance; Performance.

Artikel masuk: 29 Januari 2019

Tanggal diterima: 05 September 2019 


\section{PENDAHULUAN}

Auditor adalah seseorang yang memiliki kualifikasi tertentu dalam melakukan audit atas laporan keuangan dan kegiatan suatu perusahaan atau organisasi. Menurut Mulyadi (2014) Auditing adalah suatu proses sistematik untuk memperoleh dan mengevaluasi bukti secara objektif mengenai pernyataanpernyataan tentang kegiataan dan kejadian ekonomi dengan tujuan untuk menetapkan tingkat kesesuaian antara pernyataan-pernyataan tersebut dengan kriteria yang telah ditetapkan, serta penyampaian hasil-hasilnya kepada pemakai yang berkepentingan. Pengauditan yang dilakukan adalah pada instansi-instansi pemerintah dan perusahaan terbuka seperti perusahaan yang go public, perusahaan-perusahaan besar dan juga perusahan kecil serta organisasiorganisasi yang tidak bertujuan mencari laba. Kebutuhan perusahaan akan pengauditan kegiatan perusahaannya menunjukkan pentingnya peran auditor dalam dunia perekonomian (Sitio \& Anisykurlillah, 2014). Auditor yang bertugas melakukan audit atas keuangan pada instansi-instansi pemerintah disebut sebagai auditor pemerintah. Auditor yang bekerja pada suatu perusahaan dan oleh karenanya berstatus sebagai pegawai pada perusahaan tersebut disebut sebagai auditor internal. Tugas utamanya ditujukan untuk membantu manajemen perusahaan tempat dimana dimana auditor tersebut bekerja. Sedangkan auditor yang melakukan pengauditan pada perusahaan terbuka seperti perusahaan yang go public, perusahaan-perusahaan besar dan juga perusahan kecil serta organisasi-organisasi yang tidak bertujuan mencari laba disebut sebagai auditor independen atau akuntan publik yang harus melakukan praktik melalui suatu kantor yang disebut dengan Kantor Akuntan Publik (KAP).

Kantor Akuntan Publik (KAP) merupakan salah satu organisasi atau badan usaha yang didirikan oleh seseorang atau beberapa akuntan publik dalam memberikan jasanya sesuai dengan karakteristik profesi akuntan publik dan telah mendapatkan izin dari menteri keuangan berdasarkan peraturan perundang-undangan. Bidang jasa yang terdapat di KAP meliputi Jasa Astetasi yang didalamnya termasuk audit umum atas laporan keuangan, pemeriksaan atas laporan keuangan prospektif, pemeriksaan atas laporan informasi keuangan performa, review atas laporan keuangan, dan jasa audit serta atestasi lainnya. Sedangkan jasa non-atestasi, yang mencakup jasa yang berkaitan dengan akuntansi, keuangan, manajemen, kompilasi, perpajakan, dan konsultasi. Kinerja dari sebuah KAP sangat dipengaruhi oleh kinerja dari auditor di dalam KAP tersebut. Jika Kondisi atau keadaan kerja yang kurang kondusif hal ini akan mempengaruhi kinerja auditor, yang berdampak pada kepercayaan masyarakat terhadap akuntan publik sebagai pihak yang independen dalam pengauditan laporan keuangan. Skandal akuntansi perusahaan-perusahaan besar di Amerika-seperti Enron, Global Crossing, Worldcom dan Rite Aid-hampir semuanya melibatkan kantor akuntan publik (KAP) besar seperti The Big Five. Di Perancis KAP kelas menengah yaitu RSM Salustro Reydel melakukan kesalahan saat melakukan audit atas Vivendi Universal. Di Indonesia juga pernah terjadi hal yang sama pada kasus PT. Kimia Farma Tbk., yaitu terjadinya overstated pada laba bersih per 31 Desember 2001 yang melibatkan auditor internal perusahaan. Berdasarkan kasus-kasus diatas, hal ini bisa menjadi pembelajaran bagi profesi 
auditor di Indonesia untuk terus meningkatkan kinerja mereka karena seorang auditor yang professional akan dilihat dari kinerjanya dalam menjalankan tugas dan tanggung jawabnya.

Menurut Mangkunegara (2012:9) kinerja (prestasi kerja) adalah hasil kerja secara kualitas dan kuantitas yang dicapai oleh seorang pegawai dalam melaksanakan tugasnya sesuai dengan tanggung jawab yang diberikan kepadanya. Kinerja menjadi salah satu kunci dalam menilai berhasil atau tidaknya tujuan dari organisasi atau perusahaan serta menjadi salah satu tolak ukur yang digunakan untuk menentukan apakah suatu pekerjaan yang dilakukan akan baik atau sebaliknya. Kinerja auditor merupakan tindakan atau pelaksanaan tugas pemeriksaan yang telah diselesaikan oleh auditor dalam kurun waktu tertentu. Menurut Satwika \& Himam (2014) Kinerja Auditor adalah kemampuan dari seorang auditor dalam menghasilkan temuan atau hasil dari kegiatan pemeriksaan atas pengelolaan dan tanggung jawab keuangan yang dilakukan dalam satu tim. Kinerja dari seorang auditor dapat dilihat dari hasil kerja yang dicapai oleh auditor tersebut dalam melaksanakan tugasnya, apakah sesuai dengan tanggung jawab yang diberikan padanya atau sebaliknya. Hal ini menjadi perhatian utama dalam menilai hasil audit yang dilakukan oleh auditor bagi klien dan publik. Trisnaningsih (2007), mengemukakan bahwa kinerja auditor sebagai evaluasi terhadap pekerjaan yang dilakukan oleh atasan, rekan kerja, diri sendiri, dan bawahan langsung. Menurut Goldwasser (1993) dalam penelitian Fanani et al. (2008) pencapaian kinerja auditor yang baik harus sesuai dengan standar dan kurun waktu tertentu yang mencakup : Pertama, kualitas kerja yaitu mutu menyelesaikan pekerjaan dengan bekerja berdasar pada seluruh kemampuan dan keterampilan serta pengetahuan yang dimiliki oleh auditor. Kedua, kuantitas kerja yaitu jumlah hasil kerja yang dapat diselesaikan dengan target yang menjadi tanggung jawab pekerjaan auditor serta kemampuan untuk memanfaatkan sarana dan prasarana penunjang pekerjaan. Ketiga, ketepatan waktu yaitu ketepatan waktu yang tersedia untuk menyelesaikan pekerjaan.

Seorang auditor dapat mengalami konflik peran ketika auditor tersebut dihadapkan pada beberapa perintah yang berbeda dan kesulitan untuk menyesuaikan peran yang dimiliki dalam waktu yang bersamaan. Tuntutan utama seorang auditor bersumber dari etika profesi akuntan sedangkan tuntutan lain bisa bersumber dari sistem pengendalian yang diterapkan dalam KAP (Lubis, 2011). Konflik peran atau role conflict adalah situasi yang terjadi pada individu ketika dihadapkan pada pertentangan perilaku, pola pikir dan nilai akibat adanya ekspektasi peran yang berlainan sehingga individu mengalami kesulitan dalam melakukan suatu tindakan atau mengambil keputusan. Konflik peran timbul karena adanya dua perintah berbeda yang diterima secara bersamaan dan pelaksanaan atas salah satu perintah saja akan mengakibatkan diabaikannya perintah yang lain (Wolfe \& Snoke, dalam Agustina, 2009). Konflik peran merupakan bentuk ketidaksesuaian antara mekanisme pengendalian birokrasi dan norma, aturan, etika, maupun kemandirian dari professional (Hanna \& Firnanti, 2013). Penekanan gambaran konflik peran ini khususnya konflik peran yang dialami oleh seorang auditor adalah adanya ketidaksesuaian peran yang harus dilakukan oleh auditor yang dilihat dari tuntutan profesionalisme dari profesi auditor. Ketidaksesuaian tersebut dinilai sebagai 
sebuah bentuk konflik peran. Menurut Puspa \& Riyanto (1999), konflik peran tidak akan timbul apabila seorang profesional yang bekerja dalam suatu organisasi mau beradaptasi dengan lingkungan pengendalian organisasi tempat ia bekerja. Konflik peran merupakan suatu gejala psikologis yang bisa menimbulkan rasa tidak nyaman dan secara potensial bisa menurunkan motivasi kerja sehingga bisa berakibat pada penurunan kinerja secara keseluruhan. Efek potensial dari konflik peran sangatlah rawan, baik bagi individu maupun organisasi dalam pengertian konsekuensi emosional, seperti tekanan tinggi yang berhubungan dengan pekerjaan, kepuasan kerja, dan kinerja yang lebih rendah (Fanani et al., 2008).

Auditor dituntut untuk melaksanakan tugas dan kewajibannya sebaik mungkin dalam setiap keadaan agar kinerjanya memuaskan. Tetapi terkadang semakin banyaknya tuntutan dalam bekerja akan menyebabkan auditor merasa tertekan. Ketika tekanan-tekanan tersebut tidak mampu diatasi oleh auditor, maka akan menimbulkan stres dalam bekerja. Stres yang dialami oleh anggota organisasi juga perlu diperhatikan untuk mengetahui pengaruhnya terhadap kinerja dari anggota organisasi tersebut. Stres merupakan gangguan mental pada seseorang yang terjadi ketika ia mengalami tekanan akibat dari kegagalannya dalam memenuhi kebutuhan atau keinginannya. Jika seorang karyawan mengalami stres yang terlalu besar, maka akan mengganggu kemampuan seseorang tersebut untuk menghadapi lingkungan dan pekerjaannya. Masalah stres kerja di dalam organisasi perusahaan menjadi gejala yang penting diamati semenjak timbulnya tuntutan untuk efisiensi di di dalam pekerjaan.

Stres kerja adalah suatu kondisi ketagangan yang menciptakan adanya ketidakseimbangan fisik dan psikis yang mempengaruhi emosi, proses berpikir, dan kondisi seorang karyawan Rivai \& Sagala (2009:108) Orang-orang yang mengalami stres menjadi nervous dan merasakan kekuatiran kronis sehingga mereka sering menjadi marah-marah, agresif, tidak dapat relaks, atau memperlihatkan sikap yang tidak koorperatif (Hasibuan, 2009:204).

Auditor yang tidak mampu mengatasi stres yang dialaminya maka akan menimbulkan dampak yang merugikan bagi auditor maupun bagi organisasi atau KAP tempat auditor tersebut bekerja. Dampak bagi organisasi atau KAP tempat auditor yang bersangkutan bekerja adalah Omset dan produktivitas rendah, komitmen organisasi dan loyalitas berkurang. Sedangkan dampak yang merugikan bagi auditor adalah ketidakmampuan untuk membuat keputusan yang masuk akal, daya konsentrasi yang rendah, kurang perhatian, sangat sensitive terhadap kritik, yang akibatnya adalah penurunan pada kinerja auditor tersebut. Hal ini sejalan dengan penelitian yang dilakukan oleh Sinaga \& Sinambela (2013) bahwa stres kerja berpengaruh terhadap kinerja auditor pada kantor akuntan publik di Medan.

Di Indonesia saat ini tuntutan terhadap terwujudnya good governance sangat diperlukan oleh perusahaan manufaktur maupun non manufaktur termasuk KAP didalamnya. Menurut Trisnaningsih (2007) good governance digunakan untuk mendorong kinerja perusahaan serta memberikan kepercayaan bagi pemegang saham dan masyarakat. Good governance adalah prinsip pengelolaan perusahaan yang bertujuan untuk mendorong kinerja perusahaan serta memberikan nilai ekonomis bagi pemegang saham maupun masyarakat secara 
umum. Prinsip dari good governance terdiri dari lima aspek, yaitu, Transparansi (Transparancy), Akuntabilitas (Accountability), Pertanggungjawaban (Responsibility),Kemandirian (Independency), dan Keadilan (Fairness). Pengimplementasian good governance yang baik pada sebuah KAP akan mempengaruhi auditor yang bekerja di dalamnya yaitu berkaitan dengan pelaksanaan pengauditan yang lebih baik lagi sehingga dapat meningkatkan kinerja auditor. Seorang auditor yang memahami good governance dengan baik akan berpengaruh pada perilaku profesional akuntan dalam berkarya dengan orientasi pada kinerja yang tinggi untuk mencapai tujuan akhir sebagaimana diharapkan oleh berbagai pihak (Trisnaningsih, 2007). Pemahaman good governance bagi seorang auditor merupakan pemahaman tentang tata kelola perusahaan yang baik mengenai sistem dan struktur dengan tujuan untuk meningkatkan produktivitas. Hal ini sejalan dengan penelitian yang dilakukan oleh Wati et al. (2010) yang menyatakan bahwa auditor yang memahami good governance akan mempengaruhi kinerja dari auditor tersebut.

Good governance pada dasarnya adalah suatu konsep yang mengacu kepada proses pencapaian keputusan dan pelaksanaanya yang dapat dipertanggungjawabkan. Menurut Hanna \& Firnanti (2013) pemahaman good governance merupakan wujud penerimaan akan pentingnya suatu perangkat peraturan atau tata kelola yang baik untuk mengatur hubungan fungsi dan kepentingan berbagai pihak dalam urusan bisnis maupun pelayanan publik.

Pemahaman good governance adalah wujud penerimaan tentang pentingnya suatu tata kelola perusahaan yang baik dalam mengatur hubungan, fungsi dan kepentingan berbagai pihak baik itu dalam urusan bisnis maupunn pelayanan publik.Karyawan didalam sebuah perusahaan yang memahami dan mengimplementasikan good governance di perusahaan tersebut dapat meningkatkan nilai perusahaan bagi pemangku kepentingan, serta pengelolaan perusahaan secara profesional, transparan, efektif dan efisien.

Teori peran (role theory) dikemukakan oleh Kahn et al. (1964) dalam Agustina (2009). Teori peran adalah sebuah sudut pandang dalam sosiologi dan psikologi sosial yang menganggap sebagian besar aktivitas harian diperankan oleh kategori-kategori yang ditetapkan secara sosial. Tanggapan perilaku yang diharapkan dan dikehendaki ditunjukkan sebagai peranan sosial. Setiap peranan sosial adalah seperangkat hak, kewajiban, harapan, norma dan perilaku seseorang untuku menghadapi dan memenuhi. Teori Peran menjelaskan tentang perilaku individu sesuai dengan posisi yang ditempatinya baik itu di lingkungan kerja maupun di dalam masyarakat.

Peranan sosial menjelaskan tentang hak, tugas dan kewajiban, serta perilaku seseorang sesuai dengan posisi yang ditempatinya dalam konteks sosial tertentu. Dalam sebuah organisasi, peran membedakan perilaku seseorang yang menduduki posisi tertentu di dalam organisasi yang berfungsi mempersatukan kelompok dengan melengkapi spesialisasi dan fungsi koordinasi. Peran merupakan komponen perilaku nyata yang disebut norma yang menjadi harapan dan kebutuhan perilaku yang sesuai untuk suatu peranan tertentu dalam bertindak. Individu menerima pesan dan menginterpretasikannya, yang akan direspon dalam berbagai cara. Tetapi ketika individu tidak mengerti dan memahami pesan yang diterima karena pesan tersebut tidak jelas dan tidak 
dapat diinterpretasikan dengan mudah, serta tidak sesuai dengan daya tangkap si penerima pesan akan mengakibatkan pesan tersebut dinilai ambigu atau mengandung unsur konflik, sehingga respon dari individu akan berlawanan dengan yang diharapkan oleh si pengirim pesan. Ketika perilaku yang diharapkan individu tidak konsisten dapat menyebabkan stres pada individu, depresi dan merasa tidak puas sehingga kinerjanya akan menurun akibat dari harapan yang mengandung konflik.

Teori penilaian kognitif dikemukakan oleh (Lazarus \& Folkman, 1986). Teori ini menjelaskan mengenai proses penilaian individu terhadap tuntutan dari lingkungan yang harus dihadapi, yang berkaitan dengan sumber daya yang dimiliki oleh individu tersebut dengan kata lain individu melakukan penilain terhadap segala hal yang terjadi pada dirinya. Menurut Kurt Lewin perilaku individu dipengaruhi oleh karakteristik personal individu, seperti kemampuan, kepribadian dan disposisi genetif, dan oleh pemahamannya tentang lingkungan sosial. Mengacu pada teori ini, stres yang dihadapi auditor bergantung pada bagaimana auditor tersebut menilai dan mengatasi setiap tuntutan dalam bekerja yang dihadapi auditor. Menurut Lazarus \& Folkman (1986) teori penilaian kognitif terdiri dari dua hal yaitu primary appraisal dan secondary appraisal. Primary appraisal atau proses primer adalah proses penilaian pada saat mendeteksi suatu kejadian potensial yang menyebabkan stres. Kejadian potensial tersebut diantaranya bahaya, ancaman, dan tantangan. Bahaya (harm) adalah penilaian terhadap kerusakan yang telah diakibatkan karena suatu kejadian. Ancaman (threat) adalah penilaian terhadap kerusakan yang terjadi dimasa yang akan datang akibat dari suatu kejadian. Tantangan (challenge) adalah penilaian terhadap potensi diri untuk mengatasi situasi yang tidak menyenangkan akibat kejadian, lalu menggunakan potensi yang ada secara maksimal dari kejadian tersebut. Sedangkan secondary appraisal adalah proses mengevaluasi potensi atau kemampuan untuk mengatasi kondisi yang dihadapi. Kemudain menentukan keefektifan potensi atas kemauan yang digunakan untuk menghadapi suatu kejadian.

Seorang profesional dalam melaksanakan tugasnya sering menerima dua perintah sekaligus. Perintah pertama berasal dari kode etik profesi, sedangkan perintah yang kedua berasal dari sistem pengendalian yang berlaku di perusahaan. Apabila seorang profesional bertindak sesuai dengan kode etik, maka ia akan merasa tidak berperan sebagai karyawan perusahaan yang baik. Sebaliknya, apabila ia bertindak sesuai dengan prosedur yang ditentukan oleh perusahaan, maka ia akan merasa telah bertindak secara tidak profesional. Kondisi seperti inilah yang disebut dengan konflik peran, yaitu suatu konflik yang timbul karena mekanisame pengendalian birokratis organisasi tidak sesuai dengan norma, aturan, etika, dan kemandirian profesional. Konflik peran atau role conflict merupakan suatu gejala psikologis yang bisa menimbulkan rasa tidak nyaman dan serba salah yang secara potensial bisa menurunkan motivasi kerja sehingga bisa berakibat pada penurunan kinerja secara keseluruhan.

Konflik peran terjadi ketika seseorang menerima dua perintah sekaligus secara bersamaan dan pelaksanaan salah satu perintah akan mengakibatkan diabaikannya perintah yang lainnya. Konflik peran yang dialami auditor jika terjadi secara terus menerus akan menimbulkan ketidaknyamanan dalam bekerja 
yang akan mempengaruhi motivasi auditor dalam bekerja sehingga berdampak pada kinerja dari auditor tersebut. Penelitian yang dilakukan oleh Gunawan \& Ramdan (2012) menunjukkan hasil bahwa konflik peran tidak berpengaruh terhadap kinerja auditor Sedangkan penelitian yang dilakukan oleh Rosally \& Jogi (2015) menunjukkan hasil bahwa konflik peran berpengaruh negatif dan siginifikan terhadap kinerja auditor. Berdasarkan teori dan hasil penelitian sebelumnya, maka hipotesis yang diajukan dalam penelitian ini adalah:

$\mathrm{H}_{1}$ : Konflik peran berpengaruh negatif terhadap kinerja auditor

Menurut Putra \& Wibawa (2014) stres kerja adalah suatu kondisi dimana seorang karyawan mengalami tekanan dalam bekerja yang berasal dari tugas, pimpinan dan lingkungan tempat karyawan tersebut bekerja. Seorang auditor yang mengalami tekanan secara terus menerus dalam menjalankan tugas dan tanggungjawabnya dapat menimbulkan stres dalam bekerja. Stres yang dialami oleh seorang auditor jika tidak diatasi akan mempengaruhi pola pikir, perilaku dan emosi auditor yang akan berdampak pada kinerja dari auditor tersebut hal ini selaras dengan penelitian yang dilakukan oleh Angelina \& Ratnaningsih (2016) bahwa stres kerja berpengaruh terhadap kinerja auditor. Berdasarkan teori dan penelitian sebelumnya, maka hipotesis yang diajukan dalam penelitian ini adalah :

$\mathrm{H}_{2}$ : Stres kerja berpengaruh negatif terhadap kinerja auditor

Auditor yang memahami good governance dengan baik akan mempengaruhi perilakunya dalam menjalankan tugas dan tanggungjawabnya. Penelitian yang dilakukan oleh Sitio \& Anisykurlillah (2014) menunjukkan hasil bahwa auditor yang memahami good governance akan mempengaruhi kinerja auditor tersebut sedangkan penelitian yang dilakukan oleh Trisnaningsih (2007) menunjukkan hasil bahwa auditor yang memahami good governance tidak berpengaruh terhadap kinerja auditor tersebut. Berdasarkan teori dan hasil penelitian sebelumnya, maka hipotesis penelitian yang diajukan dalam penelitian ini adalah:

$\mathrm{H}_{3}$ : Pemahaman good governance berpengaruh positif terhadap kinerja auditor.

\section{METODE PENELITIAN}

Penelitian ini dilakukan di kantor akuntan publik di Provinsi Bali yang terdaftar dalam Direktori yang diterbitkan oleh Institut Akuntan Publik Indonesia (IAPI) pada tahun 2018. Populasi merupakan keseluruhan dari subjek penelitian. Populasi dalam penelitian ini adalah seluruh auditor yang bekerja pada KAP di Provinsi Bali. KAP yang digunakan adalah KAP yang terdaftar dalam Direktori yang diterbitkan oleh Institut Akuntan Publik Indonesia tahun 2018. Kriteria yang digunakan dalam penelitian ini adalah auditor yang telah bekerja minimal 1 tahun. Tabel 1 Berikut merupakan daftar jumlah auditor yang bekerja di Kantor Akuntan Publik Provinsi Bali tahun 2018. 
Tabel 1. Daftar Jumlah Auditor di Kantor Akuntan Publik Provinsi Bali Tahun 2018

\begin{tabular}{llcc}
\hline No & Nama Kantor Akuntan Publik & $\begin{array}{c}\text { Jumlah } \\
\text { Auditor } \\
\text { (Orang) }\end{array}$ & $\begin{array}{c}\text { Jumlah Auditor } \\
\text { sesuai kriteria } \\
\text { (Orang) }\end{array}$ \\
\hline 1 & KAP I Wayan Ramantha & 10 & 10 \\
2 & KAP Johan Malonda Mustika \& Rekan (Cabang) & 10 & 10 \\
3 & KAP K. Gunarsa & 3 & 3 \\
4 & KAP Drs. Ketut Budiartha, Msi & 8 & 8 \\
5 & KAP DRS. Ketut Muliartha RM \& Rekan & 7 & 7 \\
6 & KAP Drs. Sri Marmo Djogosarkoro \& Rekan & 10 & 10 \\
7 & KAP Drs. Wayan Sunasdyana & 5 & 5 \\
8 & KAP Arnaya \& Darmayasa & 10 & 10 \\
9 & KAP Budhananda Munidewi & 7 & 7 \\
Total & & 70 & 70 \\
\hline
\end{tabular}

Sumber: Data Penelitian, 2018

Analisis regresi linear digunakan untuk memperoleh gambaran yang menyeluruh mengenai hubungan antara variabel independen dan variabel dependen baik secara parsial maupun secara simultan. Analisis regresi linear berganda dalam penelitian ini digunakan untuk mengetahui ada tidaknya pengaruh antara konflik peran, stres kerja dan pemahaman good governance serta implikasinya terhadap kinerja auditor. Untuk menguji variabel tersebut maka digunakan rumus sebagai berikut :

$$
Y=\alpha+\beta 1 X 1+\beta 2 X 2+\beta 3 X 3+\varepsilon .
$$

Keterangan :

$\begin{array}{ll}\mathrm{Y} & : \text { Variabel Kinerja Auditor } \\ \mathrm{a} & : \text { Konstanta } \\ \beta 1, \beta 2, \beta 3 & : \text { Koefisien regresi variabel X1,X2,X3 } \\ \mathrm{X} 1 & : \text { Variabel Konflik Peran } \\ \mathrm{X} 2 & : \text { Variabel Stres Kerja } \\ \mathrm{X} 3 & : \text { Variabel Pemahaman Good Governance } \\ \varepsilon & : \text { Residual atau predicyion error }\end{array}$

\section{HASIL DAN PEMBAHASAN}

Berdasarkan hasil statistik deskriptif pada Tabel 2, nilai terendah dari konflik peran adalah sebesar 12 dan nilai tertinggi sebesar 28, sedangkan nilai rataratanya adalah sebesar 18,3333 yang berarti bahwa konflik peran yang dialami auditor yang bekerja di Kantor Akuntan Publik di Provinsi Bali berada diatas rata-rata dengan standar deviasi sebesar 3,52552 yang menunjukkan bahwa adanya perbedaan nilai dari konflik peran yang diteliti terhadap nilai rata-rata sebesar 3,52553.

Tabel 2. Hasil Uji Statistik Deskriptif

\begin{tabular}{lccccr}
\hline \multicolumn{1}{c}{ Variabel } & N & Min. & Max. & Mean & Std. Deviation \\
\hline Konflik peran & 60 & 12 & 28 & 18,3333 & 3,52553 \\
Stres Kerja & 60 & 6 & 24 & 12,3000 & 3,01015 \\
Pemahaman Good Governance & 60 & 24 & 28 & 25,2000 & 1,74473 \\
Kinerja Auditor & 60 & 23 & 32 & 26,9500 & 2,97689 \\
\hline
\end{tabular}

Sumber: Data Penelitian, 2018 
Berdasarkan hasil statistik deskriptif pada Tabel 2, nilai terendah dari stres kerja adalah sebesar 6 dan nilai tertinggi sebesar 24, sedangkan nilai rata-ratanya adalah sebesar 12,300 yang berarti bahwa stres kerja yang dialami auditor yang bekerja di Kantor Akuntan Publik di Provinsi Bali berada diatas rata-rata dengan standar deviasi sebesar 3,01015 yang menunjukkan bahwa adanya perbedaan nilai dari stres kerja yang diteliti terhadap nilai rata-rata sebesar 3,01015

Berdasarkan hasil statistik deskriptif pada Tabel 2 nilai terendah dari pemahaman good governance adalah sebesar 24 dan nilai tertinggi sebesar 28 sedangkan nilai rata-ratanya adalah sebesar 25,2000 yang berarti bahwa pemahaman good governance auditor yang bekerja di Kantor Akuntan Publik di Provinsi Bali berada diatas rata-rata dengan standar deviasi sebesar 1,74473 yang menunjukkan bahwa adanya perbedaan nilai dari pemahaman good governance yang diteliti terhadap nilai rata-rata sebesar 1,74473.

Berdasarkan hasil statistik deskriptif pada Tabel 2, nilai terendah dari kinerja auditor adalah sebesar 23 dan nilai tertinggi sebesar 32 sedangkan nilai rata-ratanya adalah sebesar 26,9500 yang berarti bahwa kinerja auditor yang bekerja di Kantor Akuntan Publik di Provinsi Bali berada diatas rata-rata dengan standar deviasi sebesar 2,97689 yang menunjukkan bahwa adanya perbedaan nilai dari kinerja auditor yang diteliti terhadap nilai rata-rata sebesar 2,97689.

Tabel 3. Hasil Uji Validitas

\begin{tabular}{|c|c|c|c|c|}
\hline No & Variabel & $\begin{array}{c}\text { Item } \\
\text { Pernyataan }\end{array}$ & $\begin{array}{c}\text { Pearson } \\
\text { Correlation }\end{array}$ & Keterangan \\
\hline \multirow[t]{7}{*}{1} & Konflik Peran & $\mathrm{X} 1.1$ & 0,760 & Valid \\
\hline & & $\mathrm{X} 1.2$ & 0,812 & Valid \\
\hline & & $\mathrm{X} 1.3$ & 0,833 & Valid \\
\hline & & X1.4 & 0,758 & Valid \\
\hline & & X1.5 & 0,712 & Valid \\
\hline & & X1.6 & 0,682 & Valid \\
\hline & & $\mathrm{X} 1.7$ & 0,783 & Valid \\
\hline \multirow[t]{6}{*}{2} & Stres Kerja & X2.1 & 0,651 & Valid \\
\hline & & $\mathrm{X} 2.2$ & 0,796 & Valid \\
\hline & & $\mathrm{X} 2.3$ & 0,878 & Valid \\
\hline & & X2.4 & 0,793 & Valid \\
\hline & & X2.5 & 0,816 & Valid \\
\hline & & X2.6 & 0,758 & Valid \\
\hline \multirow[t]{6}{*}{3} & Pemahaman Good Governance & X3.1 & 0,737 & Valid \\
\hline & & $\mathrm{X} 3.2$ & 0,758 & Valid \\
\hline & & X3.3 & 0,713 & Valid \\
\hline & & X3.4 & 0,717 & Valid \\
\hline & & X3.5 & 0,646 & Valid \\
\hline & & X3.6 & 0,756 & Valid \\
\hline \multirow[t]{7}{*}{4} & Kinerja Auditor & $X 4.1$ & 0,788 & Valid \\
\hline & & $X 4.2$ & 0,828 & Valid \\
\hline & & X4.3 & 0,651 & Valid \\
\hline & & X4.4 & 0,771 & Valid \\
\hline & & X4.5 & 0,818 & Valid \\
\hline & & $X 4.6$ & 0,728 & Valid \\
\hline & & X4.7 & 0,644 & Valid \\
\hline
\end{tabular}

Sumber: Data Penelitian, 2018 
Berdasarkan Tabel 3 diatas dapat diketahui bahwa seluruh indikator atau instrumen pernyataan dalam variabel konflik peran, stres kerja, pemahaman good governance dan kinerja auditor memenuhi syarat validitas karena nilai korelasi antar skor tiap pernyataan menunjukan hasil yang signifikan dan nilainya yang lebih besar dari 0,30.

Jika suatu kontruk atau variabel memiliki nilai cronbach Alpha $>0.70$ maka dapat dikatakan bahwa kontruk atau variabel tersebut reliabel (Ghozali, 2016). Jumlah item dalam kuesioner penelitian ini adalah 26 item. Hasil uji reliabilitas penelitian ini ditunjukkan pada Tabel 4 berikut ini.

\section{Tabel 4. Hasil Uji Reliabilitas}

\begin{tabular}{cccc}
\hline No & Variabel & Cronbach Alpha & Keterangan \\
\hline 1 & Konflik Peran & 0,874 & Reliabel \\
2 & Stres Kerja & 0.869 & Reliabel \\
3 & Pemahaman Good Governance & 0.816 & Reliabel \\
4 & Kinerja Auditor & 0,865 & Reliabel \\
\hline
\end{tabular}

Sumber: Data Penelitian, 2018

Berdasarkan hasil uji reliabilitas pada Tabel 4 diatas dapat diketahui bahwa variabel yang digunakan dalam penelitian ini adalah reliabel dan layak digunakan menjadi alat ukur instrumen kuesioner dalam penelitian ini karena nilai Cronbach Alpa dari keseluruhan variabel lebih besar dari 0,70.

Uji normalitas bertujuan untuk mengetahui apakah masing - masing variabel berdistribusi normal atau tidak.. Uji statistik yang digunakan untuk uji normalitas data dalam penelitian ini adalah uji Kolmogorov-Smirnov. Data yang dihasilkan dinyatakan berdistribusi normal apabila nilai Asymp. Sig (2-tailed) yang dihasilkan $>0,05$.

\section{Tabel 5. Hasil Uji Normalitas}

\begin{tabular}{llrr}
\hline & & \multicolumn{2}{c}{ Unstandardized Residual } \\
\hline $\mathrm{N}$ & & 60 &, 0000000 \\
Normal Parameters ${ }^{a, b}$ & Mean & & 2,52931286 \\
& Std. Deviation & &, 107 \\
Most Extreme Differences & Absolute & &, 104 \\
& Positive & &,- 107 \\
& Negative &, 107 & \\
Test Statistic & &, $086^{\mathrm{c}}$ & \\
Asymp. Sig. (2-tailed) & &
\end{tabular}

Sumber: Data Penelitian, 2018

Berdasarkan Tabel 5 dapat dilihat bahwa nilai Asymp. Sig. (2-tailed) adalah sebesar 0,086, yang berarti bahwa data berdistribusi normal karena nilai dari Asymp. Sig (2-tailed) lebih besar dari 0,05.

Uji multikolinearitas dilakukan dengan melihat tolerance value dan variance inflation factor (VIF). Multikolinearitas terjadi bila nilai VIF diatas nilai 10 atau tolerance value dibawah 0,10 . Multikolinearitas tidak terjadi bila nilai VIF dibawah nilai 10 atau tolerance value diatas 0,10. 


\section{Gambar 6. Hasil Uji Multikolinearitas}

\begin{tabular}{llcc}
\hline No & \multicolumn{1}{c}{ Variabel } & \multicolumn{2}{c}{ Collinearty Statistic } \\
\cline { 3 - 4 } & & Tolerance & VIF \\
\hline 1 & Konflik Peran & 0,804 & 1,244 \\
2 & Stres Kerja & 0,775 & 1,290 \\
3 & Pemahaman Good Governance & 0,960 & 1,042 \\
\hline
\end{tabular}

Sumber: Data Penelitian, 2018

Berdasarkan Tabel 6 dapat dilihat bahwa nilai tolerance dari variabel konflik peran, stres kerja dan pemahaman good governance $>$ dari 0,10 dan nilai VIFnya $<10$ yang berarti bahwa tidak terjadi multikolinearitas pada data dalam penelitian ini.

Pada penelitian ini digunakan uji Glejser dengan meregresikan nilai absolute ei dengan variabel bebas. Jika tidak ada satupun variabel bebas yang berpengaruh signifikan terhadap variabel terikat (nilai absolute ei), maka tidak ada heteroskedastisitas.

Tabel 7. Hasil Uji Heteroskedastisitas

\begin{tabular}{|c|c|c|}
\hline No & Variabel & Sig. \\
\hline 1 & Konfik Peran & 0,951 \\
\hline 2 & Stres Kerja & 0,119 \\
\hline 3 & Pemahaman Good Governance & 0,453 \\
\hline
\end{tabular}

Sumber: Data Penelitian, 2018

Berdasarkan hasil uji statistik pada Tabel 7 dapat dilihat bahwa nilai Sig. dari variabel konflik peran, stres kerja, dan pemahaman good governance lebih besar dari 0,05 .Hal ini berarti tidak terjadi heteroskedastisitas terhadap model regresi dalam penelitian ini.

Analisis regresi linear digunakan untuk mengetahui ada tidaknya pengaruh antara konflik peran ganda, stres kerja dan pemahaman good governance serta implikasinya terhadap kinerja auditor. Berdasarkan hasil olah data dengan bantuan SPSS, maka didapatkan hasil seperti pada Tabel 8 berikut ini.

Tabel 8. Hasil Analisis Regresi Linear Berganda

\begin{tabular}{|c|c|c|c|c|c|}
\hline \multirow[t]{2}{*}{ Model } & \multicolumn{2}{|c|}{$\begin{array}{l}\text { Unstandardized } \\
\text { Coefficients }\end{array}$} & \multirow{2}{*}{$\begin{array}{c}\begin{array}{c}\text { Standardized } \\
\text { Coefficients }\end{array} \\
\text { Beta }\end{array}$} & \multirow[t]{2}{*}{$t$} & \multirow[t]{2}{*}{ Sig. } \\
\hline & $B$ & $\begin{array}{c}\text { Std. } \\
\text { Error }\end{array}$ & & & \\
\hline (Constant) & 22,532 & 5,110 & & 4,410 & ,000 \\
\hline Konflik Peran &,- 414 & 107 &,- 490 & $-3,867$ & ,000 \\
\hline Stres Kerja & ,054 & 128 & ,055 & ,423 & 674 \\
\hline $\begin{array}{l}\text { Pemahaman Good } \\
\text { Governance }\end{array}$ & ,450 & 198 & 264 & 2,275 & ,027 \\
\hline
\end{tabular}

Adjusted $\mathrm{R}^{2}=0,278$

Fhitung $\quad=7,191$

$\mathrm{F}_{\text {signifikan }} \quad=0,000$

Sumber: Data Penelitian, 2018

Berdasarkan Tabel 8 dapat disusun persamaan regresi pada penelitian ini dapat disusun sebagai berikut.

$$
\mathrm{Y}=22,532-0,414 \mathrm{X} 1+0,054 \mathrm{X} 2+0,450 \mathrm{X} 3+\mathrm{e}
$$


Keterangan :

$\begin{array}{ll}\mathrm{Y} & : \text { Kinerja Auditor } \\ \mathrm{a} & : \text { Konstanta } \\ \beta 1, \beta 2, \beta 3 & : \text { Koefisien regresi variabel X1,X2,X3 } \\ \mathrm{X} 1 & : \text { Konflik Peran } \\ \mathrm{X} 2 & : \text { Stres Kerja } \\ \mathrm{X} 3 & : \text { Pemahaman Good Governance } \\ \varepsilon & : \text { Residual atau predicyion error }\end{array}$

Nilai konstanta $=22,532$ menjelaskan bahwa jika variabel konflik peran, stres kerja dan pemahaman good governance maka variabel kinerja auditor adalah sebesar 22,532 satuan dengan asumsi variabel bebas lainnya konstan.

Nilai koefisien regresi $=-0,414$ menunjukkan bahwa jika konflik peran (X1) sebesar 1, maka nilai dari kinerja auditor $(Y)$ akan mengalami penurunan sebesar 0,414 satuan dengan asumsi variabel bebas lainnya konstan.

Nilai koefisien regresi $=0,054$ menunjukkan bahwa jika stres kerja (X2) sebesar 1, maka nilai dari kinerja auditor akan mengalami peningkatan sebesar 0,054 satuan dengan asumsi variabel bebas lainnya konstan.

Nilai koefisien regresi $=0,450$ menunjukkan bahwa jika pemahaman good governance pada auditor sebesar 1, maka nilai dari kinerja auditor akan mengalami peningkatan sebesar 0,450 dengan asumsi variabel bebas lainnya konstan.

Berdasarkan Tabel 8 nilai signifikan $\mathrm{F}$ adalah sebesar 0,000 yang lebih kecil dari nilai $a=0,05$, sehingga dapat dikatakan bahwa model regresi yang digunakan dalam penelitian ini layak digunakan sebagai alat analisis untuk menguji pengaruh variabel bebas terhadap variabel terikat. Dengan melihat nilai signifikan yang lebih kecil < 0,05 yang menjelaskan bahwa konflik peran, stres kerja dan pemahaman good governance berpengaruh secara simultan atau serempak terhadap kinerja auditor.

Berdasarkan Tabel 8 hasil analisis menunjukkan nilai $\mathrm{R}_{\text {square }}$ sebesar 0,278. Hal ini berarti bahwa 27,80 persen dari total variasi (naik-turunnya) kinerja auditor dapat dijelaskan oleh konflik peran, stres kerja dan pemahaman good governance auditor dan sisanya 72,20 persen dipengaruhi atau dijelaskan oleh faktor-faktor lain yang tidak diuji dalam penelitian ini.

Berdasarkan Tabel 7 dapat dilihat nilai koefisien regresi untuk variabel konflik peran sebesar -0,414 dengan tingkat signifikansi sebesar 0,000 $<0,05$, yang berarti $\mathrm{H}_{1}$ diterima. Hal ini menjelaskan bahwa konflik peran berpengaruh negatif dan signifikan terhadap kinerja auditor.

Berdasarkan Tabel 8 dapat dilihat nilai koefisien regresi untuk variabel stres kerja adalah sebesar 0,054 dengan tingkat singnifikansi sebesar 0,674 > 0,05, yang berarti $\mathrm{H}_{2}$ ditolak. Hal ini menjelaskan bahwa stres kerja tidak berpengaruh secara signifikan terhadap kinerja auditor.

Berdasarkan Tabel 8 dapat dilihat bahwa nilai koefisien regresi untuk variabel pemahaman good governance sebesar 0,450 dengan tingkat signifikansi sebesar $0,027<0,05$, yang berarti $\mathrm{H}_{3}$ diterima. Hal ini menjelaskan bahwa pemahaman good governance berpengaruh positif dan signifikan terhadap kinerja auditor. 
Hasil pengujian menunjukkan bahwa variabel konflik peran berpengaruh negatif dan signifikan terhadap kinerja auditor, maka hipotesis pertama $\left(\mathrm{H}_{1}\right)$ diterima. Hal ini berarti bahwa semakin tinggi konflik peran yang dialami auditor maka kinerja auditor tersebut semakin menurun.

Hasil penelitian ini didukung oleh penelitian yang dilakukan Hanif (2013), Ismarhadi (2016) serta Rosally \& Jogi (2015) yang menyatakan bahwa konflik peran berpengaruh negatif dan signifikan terhadap kinerja auditor. Hal ini menunjukkan bahwa auditor mengalami konflik peran karena masih melakukan pekerjaan dengan tenaga kerja atau SDM yang kurang, mengesampingkan aturan untuk menyelesaikan pekerjaan, melakukan kegiatan yang seharusnya tidak perlu dan bekerja dengan arahan yang tidak jelas. Konflik peran yang dialami seorang auditor dapat menimbulkan tekanan dan rasa tidak nyaman dalam bekerja yang dapat menurunkan motivasi auditor tersebut dalam bekerja yang berakibat pada penurunan kinerja auditor secara keseluruhan.

Hasil pengujian menunjukkan bahwa variabel stres kerja tidak berpengaruh secara signifikan terhadap kinerja auditor, maka hipotesis kedua $\left(\mathrm{H}_{2}\right)$ ditolak. Hal ini berarti bahwa stres kerja yang dialami oleh auditor karena tekanan yang berasal dari tuntutan tugas, pimpinan dan lingkungan kerja dapat diatasi atau dikendalikan oleh auditor dengan baik sehingga stres yang dialami auditor tidak mempengaruhi kinerja auditor tersebut.

Hasil penelitian ini selaras dengan penelitian yang dilakukan Fattahanifa (2017) yang menyatakan bahwa stres kerja tidak berpengaruh secara signifikan terhadap kinerja auditor karena para auditor mampu mengatasi dengan baik tekanan yang dialaminya dalam melaksanakan tugas dan tangggungjawabnya. Faktor yang mendasari stres kerja tidak berpengaruh terhadap kinerja auditor karena profesionalitas auditor dalam bekerja sehingga auditor harus tetap melaksanakan tugas dan tanggungjawabnya meskipun mendapatkan tekananan dari pimpinan atau lingkungan kerja maupun masalah yang dialami auditor diluar lingkungan kerja.

Stres kerja tidak dapat dihindari, namun dapat dikurangi dan dikelola. Stres kerja yang dikelola dengan baik dapat menjadi pendorong dan meningkatkan intensitas kerja, sedangkan apabila tidak dikeloa dengan baik stres kerja akan menimbulkan permasalahan yang berdampak negatif bagi individu dan perusahaan. Auditor menanggapi dengan positif stres kerja yang dialami yang menjadi peluang karena stres tersebut merangsang auditor untuk meningkatkan usahanya dengan memperoleh hasil yang maksimal. Hal ini sesuai dengan teori yang digunakan dalam penelitian ini yaitu teori penilaian kognitif bahwa stres yang dialami auditor merupakan hasil dari penilaian auditor mengenai situasi yang dialami auditor. Kemudian auditor mengatasi stres yang dialami melalui potensi-potensi yang dimiliki auditor.

Hasil pengujian menunjukkan bahwa variabel pemahaman good governance oleh auditor berpengaruh positif dan signifikan terhadap kinerja auditor, maka $\mathrm{H}_{3}$ diterima. Hal ini berarti bahwa semakin baik pemahaman auditor mengenai good governance maka kinerja auditor tersebut semakin meningkat.

Hal ini sesuai dengan penelitian yang dilakukan oleh Yusriwarti (2013) dan Dewi \& Mastra (2016) yang menyatakan bahwa pemahaman good governance 
berpengaruh positif dan signifikan terhadap kinerja auditor. Auditor yang memahami fungsi dan tata kelola yang baik dalam suatu organisasi khususnya di Kantor Akuntan Publik dapat mewujudkan kondisi lingkungan kerja yang baik, sehingga dalam pelaksanaan tugasnya kinerja auditor menjadi lebih baik pula yang berdampak pada peningkatan produktivitas dari Kantor Akuntan Publik. Seorang auditor yang memahami good governance secara benar maka akan mempengaruhi prilaku profesional auditor dalam melaksanakan tugasnya dengan orientasi memperoleh hasil yang baik sehingga kinerjanya akan meningkat.

Hasil penelitian ini dapat memberikan tambahan informasi mengenai kajian

empiris pengaruh konflik peran, stres kerja dan pemahaman good governance terhadap kinerja auditor. Dalam penelitian ini terdapat bukti empiris yang menunjukkan bahwa adanya pengaruh konflik peran terhadap kinerja auditor dan bukti empiris mengenai adanya pengaruh pemahaman good governance auditor terhadap kinerja auditor. Penelitian ini diharapkan dapat dijadikan penyempurnaan dan perbandingan dari penelitian terdahulu mengenai kinerja auditor.

Hasil penelitian ini diharapkan dapat memberikan masukkan bagi auditor

mengenai pengaruh konflik peran, stres kerja, dan pemahaman good governance terhadap kinerja auditor sehingga auditor dapat mengatasi konflik peran yang dialami, mengendalikan stres dalam bekerja serta meningkatkan pemahaman tentang good governance agar kinerja auditor lebih baik lagi. Hasil penelitian ini juga diharapkan dapat memberikan manfaat bagi investor, klien maupun pihakpihak yang berkepentingan lainnya dalam menilai produktivitas sebuah Kantor Akuntan Publik yang salah satunya dapat dilihat dari kinerja auditornya.

\section{SIMPULAN}

Konflik peran berpengaruh negatif dan signifikan terhadap kinerja auditor. Semakin tinggi konflik peran yang dialami auditor maka kinerja auditor akan semakin rendah.

Stres kerja tidak berpengaruh terhadap kinerja auditor. Stres kerja yang dialami auditor ditanggapi dengan positif oleh auditor, sehingga stres tersebut menjadi peluang atau keuntungan karena merangsang auditor untuk meningkatkan usahanya dengan memperoleh hasil yang maksimal.

Pemahaman good governance berpengaruh positif dan signifikan terhadap kinerj auditor. Semakin baik pemahaman auditor mengenai good governance akan mempengaruhi kinerja auditor tersebut.

Bagi auditor agar memiliki sikap mental yang tangguh dalam menjalankan profesi sebagai akuntan publik serta mencari dan mengatasi masalah konflik peran yang dialami auditor karena konfik peran adalah hal yang lumrah terjadi dalam praktik dunia kerja yang harus dihadapi oleh auditor sehingga nantinya tidak menimbulkan pengaruh terhadap kinerja auditor, serta meningkatkan pemahaman mengenai good governance agar dapat diterapkan dalam bekerja sehingga dapat mendorong peningkatan kinerjanya. 
Bagi Kantor Akuntan Publik (KAP) agar memberikan pembagian tugas dan arahan yang jelas bagi auditor untuk mengatasi terjadinya konflik peran dalam bekerja. Hasil penelitian ini diharapkan agar dapat menjadi referensi tambahan bagi peneliti selanjutnya dengan menambah variabel-variabel lain selain konflik peran, stres kerja dan pemahaman good governance sehingga akan diketahui faktor-faktor lain yang mempengaruhi kinerja auditor yang bekerja di Kantor Akuntan Publik di Provinsi Bali.

\section{REFERENSI}

Agustina, L. (2009). Pengaruh Konflik Peran, Ketidakjelasan Peran, dan Kelebihan Peran terhadap Kepuasan Kerja dan Kinerja Auditor (Penelitian Kantor Akuntan Publik yang Bermitra dengan Kantor Akuntan Publik Big Four di Wilayah DKI Jakarta). Jurnal Akuntansi, 1(1), 40-69. https:// doi.org/10.1103/PhysRevLett.88.185505

Angelina, F. P., \& Ratnaningsih, I. Z. (2016). Pada Anggota Sat Lantas Polrestabes Semarang. Jurnal Empati, 5(2), 331-335.

Dewi, P. P., \& Mastra, I. M. (2016). Pengaruh Budaya Etis Organisasi dan Pemahaman Good Governance pada Kinerja Auditor Kantor Akuntan Publik di Bali. Jurnal Ilmiah Akuntansi Dan Bisnis, 1(1), 81-94.

Fanani, Z., Hanif, R. A., \& Subroto, B. (2008). Pengaruh Struktur Audit, Konflik Peran, Dan Ketidakjelasan Peran Terhadap Kinerja Auditor. Jurnal Akuntansi Dan Keuangan Indonesia, 5(2), 139-155. https://doi.org/10.1017/CBO9781107415324.004

Fattahanifa, R. (2017). Pengaruh Stres Kerja, Kepribadian, Budaya Organisasi, Job Design, Dan Emotional Quotient Terhadap Kinerja Auditor Di Kantor Akuntan Publik Yogyakarta. Universitas Muhammadiyah Surakarta.

Gunawan, H., \& Ramdan, Z. (2012). Pengaruh Konflik Peran, Ketidakjelasan Peran, Kelebihan Peran, Dan Gaya Kepemimpinan Terhadap Kinerja Auditor Di Kantor Akuntan Publik Wilayah DKI Jakarta. Accounting Department, Faculty of Economic and Communication, 3(2), 825-839. https://doi.org/https://doi.org/10.21512/bbr.v3i2.1365

Hanif, R. A. (2013). Pengaruh Struktur Audit, Konflik Peran, Dan Ketidakjelasan Peran Terhadap Kinerja Auditor. Jurnal Ekonomi, 21(3), 1-15.

Hanna, E., \& Firnanti, F. (2013). Faktor-Faktor yang Memengaruhi Kinerja Auditor. Jurnal Bisnis Dan Akuntansi, 15(1), 13-28. Retrieved from http://www.tsm.ac.id/JBA

Hasibuan, M. S. . (2009). Manajemen Sumber Daya Manusia (7th ed.). Jakarta: PT. Bumi Aksara.

Ismarhadi, M. I. (2016). Pengaruh Konflik Peran, Ketidakjelasan Peran, Independensi, Dan Komitmen Organisasi Terhadap Kinerja Auditor (Studi pada Kantor Akuntan Publik di Surakarta dan Semarang). Universitas Muhammadiyah Surakarta.

Lazarus, R. S., \& Folkman, S. (1986). Appraisal, Coping, Health Status, and Psychological Symptoms. Journal of Personality and Social Psychology, 50(3), 571-579. https:// doi.org/10.1037/0022-3514.50.3.571

Lubis, A. I. (2011). Akuntansi Keprilakuan (2nd ed.). Jakarta: Salemba Empat.

Mangkunegara, A. . A. P. (2012). Evaluasi Kinerja Sumber Daya Manusia. Bandung: PT. Refika Aditama. 
Mulyadi. (2014). Auditing Buku 1 (6th ed.). Jakarta: Salemba Empat.

Puspa, D. F., \& Riyanto, B. (1999). Tipe Lingkungan Pengendalian Organisasi, Orientasi Profesional, Konflik Peran, Kepuasan Kerja dan Kinerja: Suatu Penelitian Empiris. Jurnal Riset Akuntansi Indonesia, 2(1), 117-135.

Putra, I. G. S., \& Wibawa, I. M. A. (2014). Pengaruh Stres Kerja dan Komitmen Organisasi Terhadap Kepuasan Kerja Berdasarkan Gender pada Warong Miyabi Bali. E-Jurnal Manajemen Universitas Udayana, 3(9), 2745-2766. Retrieved from https://ojs.unud.ac.id/index.php/Manajemen/article/view/9319

Rivai, V., \& Sagala, E. . (2009). Manajemen Sumber Daya Manusia untuk Perusahaan. Jakarta: Rajagrafindo Persada.

Rosally, C., \& Jogi, Y. (2015). Pengaruh Konflik Peran, Ketidakjelasan Peran, Dan Komitmen Organisasi Terhadap Kinerja Auditor. Business Accounting Review, 3(2), 31-40.

Satwika, P. A., \& Himam, F. (2014). Kinerja Karyawan Berdasarkan Keterbukaan Terhadap Pengalaman, Organizational Citizenship Behavior dan Budaya Organisasi. Jurnal Psikologi, 41(2), 205-217. https:// doi.org/10.22146/jpsi.6950

Sinaga, T., \& Sinambela, M. (2013). Pengaruh Stress Kerja Terhadap Motivasi dan Kinerja Auditor Pada Kantor Akuntan Publik di Kota Medan. Jurnal Akuntansi, XVII(01), 75-83.

Sitio, R., \& Anisykurlillah, I. (2014). Pengaruh Pemahaman Good Governance, Gaya Kepemimpinan, Budaya Organisasi Dan Struktur Audit Terhadap Kinerja Auditor (Studi Empiris Pada Kantor Akuntan Publik Di Kota Semarang). Accounting Analysis Journal, 3(1), 361-369. https://doi.org/https:/ / doi.org/10.15294/ aaj.v3i3.4198

Trisnaningsih, S. (2007). Independensi auditor dan komitmen organisasi sebagai mediasi pengaruh pemahaman. Simposium Nasional Akuntansi X. https://doi.org/10.1590/S0104-14282003000200006

Wati, E., Lismawati, \& Aprilla, N. (2010). Pengaruh Independensi, Gaya Kepemimpinan, Komitmen Organisasi, Dan Pemahaman Good Governance Terhadap Kinerja Auditor Pemerintah (Studi Pada Auditor Pemerintah di BPKP Perwakilan Bengkulu). Simposium Nasional Akuntansi XIII.

Yusriwarti. (2013). Pengaruh Pemahaman Good Governance Terhadap Kinerja Auditor. Jurnal Akuntansi Dan Keuangan, 3(1), 1-8. 